Prepared for the U.S. Department of Energy

under Contract DE-AC05-76RL01830

\title{
A Review of Metal Concentrations Measured in Surface Soil Samples Collected on and Around the Hanford Site
}

BG Fritz

July 2009

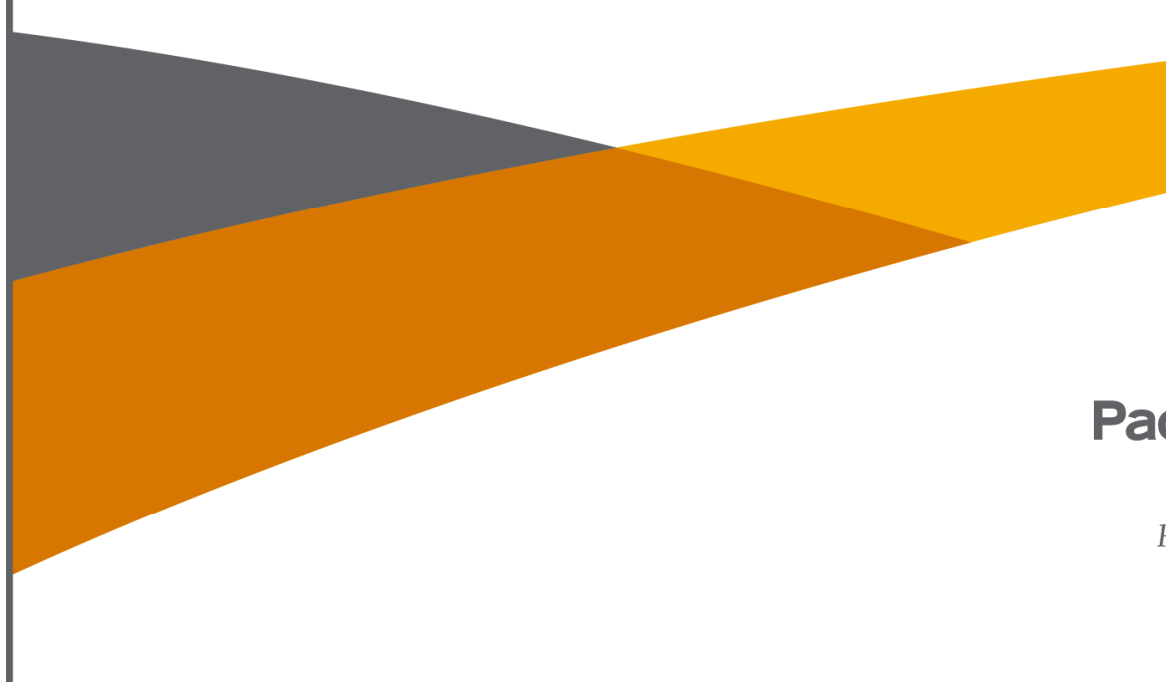




\title{
DISCLAIMER
}

This report was prepared as an account of work sponsored by an agency of the United States Government. Neither the United States Government nor any agency thereof, nor Battelle Memorial Institute, nor any of their employees, makes any warranty, express or implied, or assumes any legal liability or responsibility for the accuracy, completeness, or usefulness of any information, apparatus, product, or process disclosed, or represents that its use would not infringe privately owned rights. Reference herein to any specific commercial product, process, or service by trade name, trademark, manufacturer, or otherwise does not necessarily constitute or imply its endorsement, recommendation, or favoring by the United States Government or any agency thereof, or Battelle Memorial Institute. The views and opinions of authors expressed herein do not necessarily state or reflect those of the United States Government or any agency thereof.

\author{
PACIFIC NORTHWEST NATIONAL LABORATORY \\ operated by \\ BATTELLE \\ for the \\ UNITED STATES DEPARTMENT OF ENERGY \\ under Contract DE-AC05-76RL01830
}

Printed in the United States of America
Available to DOE and DOE contractors from the Office of Scientific and Technical Information,
P.O. Box 62, Oak Ridge, TN 37831-0062;
ph: (865) 576-8401
fax: (865) 576-5728
email: reports@adonis.osti.gov

\begin{abstract}
Available to the public from the National Technical Information Service, U.S. Department of Commerce, 5285 Port Royal Rd., Springfield, VA 22161 ph: (800) 553-6847 fax: $(703) 605-6900$

email: orders@ntis.fedworld.gov

online ordering: http://www.ntis.gov/ordering.htm
\end{abstract}




\section{A Review of Metal Concentrations Measured in Surface Soil Samples Collected on and Around the Hanford Site}

BG Fritz

July 2009

Prepared for

the U.S. Department of Energy

under Contract DE-AC05-76RL01830

Pacific Northwest National Laboratory

Richland, Washington 99352 



\section{Summary}

As part of the routine Hanford Site environmental surveillance program, researchers with the Surface Environmental Surveillance Project (SESP) collected soil samples at 41 locations on and around the Hanford Site in 2008. These samples were analyzed for metals in addition to the normal radiological constituents. In 2004 and 2005, soil samples were collected at 117 locations on the Hanford Reach National Monument (HRNM) and analyzed for radionuclides in support of the radiological release of that property. In 2008, archived HRNM soil samples (which were deemed expendable) were analyzed by SESP researchers for metals to supplement the radiological analyses previously performed, to expand the geographical coverage of the metals data set.

Concentration results for 30 individual metals were generated by the analytical methods. Selenium and antimony were typically not measured at detectable concentrations. Mercury was detected in about half of the samples analyzed. All other constituents were measured at detectable concentrations in nearly all samples analyzed.

The mean concentrations measured in this study were well below the soil cleanup levels for unrestricted land use established by the Model Toxics Control Act (MTCA). In addition to the average concentration being less than the benchmark, the 90th percentile concentration also was lower than the benchmark for the metals included in the MTCA.

The results indicate that the measured concentrations of metals in surface soil were within the expected range of concentrations and consistent with previous results from samples collected on and around the Hanford Site. 



\section{Contents}

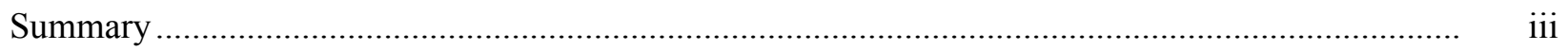

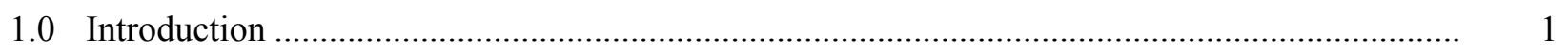

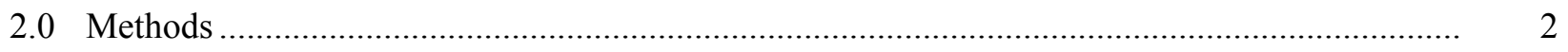

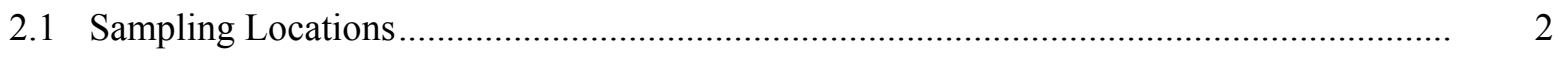

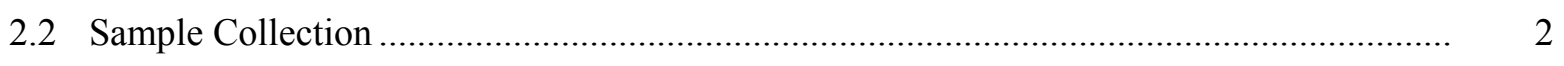

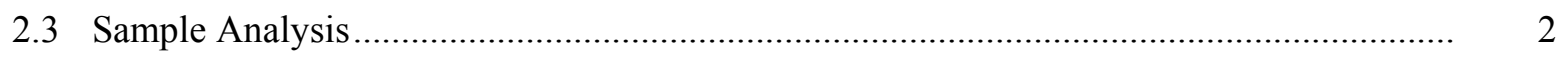

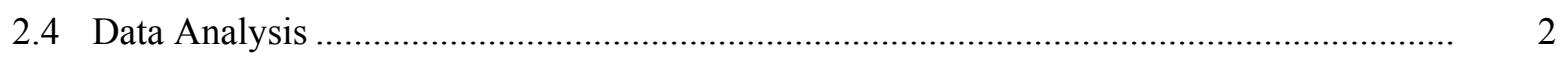

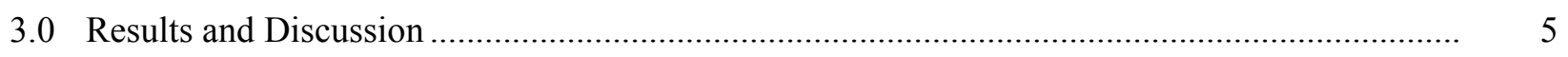

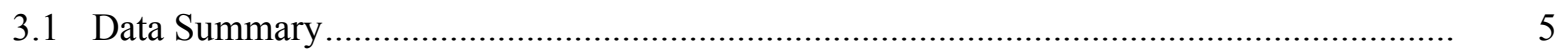

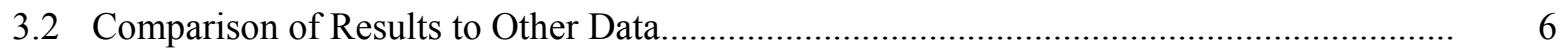

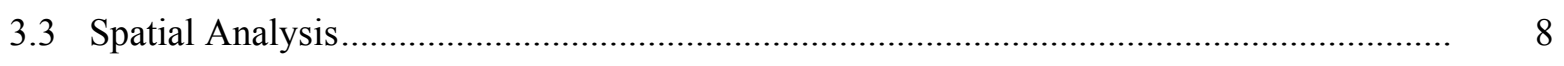

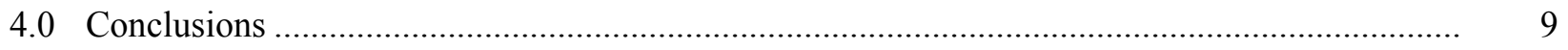

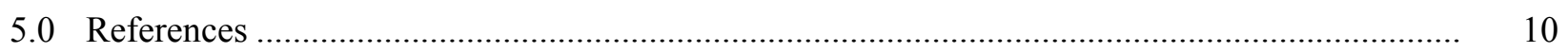

Appendix - Inter-Laboratory Comparison ..................................................................... A. A

\section{Figures}

1 Locations of Soil Samples Collected in 2004, 2005, and 2008 and Analyzed for Metals in 2008

2 Average of Samples Collected on the Hanford Site for This Study and for Risk Studies, and of Samples of Columbia River Sediment Analyzed for Metals.

3 Selected Metals Concentrations Measured on and Around the Hanford Site Compared to Hanford Background Concentrations, Southeastern Washington Averages, and U.S. Average for Sandy Soils......

4 Contoured Arsenic Concentrations and Sample Locations.

\section{Tables}

1 Number of Soil Samples Collected Between 2005 and 2008

2 Comparison of Model Toxics Control Act Metals Cleanup Levels for Unrestricted Use and Measured Concentrations of Listed Metals 



\subsection{Introduction}

For more than 40 years, U.S. Department of Energy (DOE) Hanford Site facilities were dedicated primarily to the production of plutonium for national defense and management of the resulting waste. The current Hanford Site mission focuses on cleaning up and shrinking the footprint of DOE operations. The cleanup mission includes restoring the Columbia River corridor, transitioning the Central Plateau, and preparing for the future by getting ready for long-term stewardship of DOE lands (DOE 2001).

For many years, samples of surface soil have been collected routinely on and around the Hanford Site for environmental monitoring purposes. Historically, these samples have been analyzed for radiological constituents. Only a few limited site-specific studies have analyzed surface soil samples for metals concentrations. In 2008, routine environmental samples collected at onsite and offsite sampling locations were analyzed for metals. Further, archived samples collected from the Hanford Reach National Monument in 2004 and 2005 were analyzed for metals concentrations in 2008. This provided an extensive date set for comparison.

Soil samples were collected by two separate projects; however, collection methodology was consistent, and the analysis was conducted by the same analytical laboratory using the same analytical procedures. The Surface Environmental Surveillance Project (SESP) currently oversees the collection and analysis of both onsite and offsite environmental samples, including soil and sediment (Bisping 2008). In 2008, the SESP collected samples at 41 locations on and around the Hanford Site, and had them analyzed for metals in addition to the normal radiological constituents (Poston et al. 2009). In 2004 and 2005, soil samples were collected at 117 locations on the Hanford Reach National Monument (HRNM) in support of the radiological release of that property (Fritz et al. 2007a, 2007b). In 2008, archived HRNM soil samples were analyzed for metals to supplement the radiological analyses. Combined, these two data sets constitute 158 soil samples, which enhance the existing state of knowledge regarding metals concentrations in surface soil on and around the Hanford Site. This report summarizes concentrations of metals measured in soil samples collected on and around the Hanford Site for future reference. 


\subsection{Methods}

\subsection{Sampling Locations}

The samples collected for these projects were drawn from locations centered around the Hanford Site, but the sampling locations ranged from Sunnyside, Washington, to the west; Walla Walla, Washington, to the east; as far north as George, Washington; and as far south as Umatilla, Oregon (Figure 1). Samples collected in 2008 by SESP researchers were collected at established environmental monitoring locations (Bisping 2008). These locations have been sampled repeatedly for many years (Poston et al. 2005). For the HRNM sampling effort, the sampling and analysis plan prepared prior to conducting this sampling provides detail about the methodology used to plan and conduct this soil sampling (Fritz et al. 2004; Fritz and Dirkes 2005).

\subsection{Sample Collection}

All samples discussed in this report were collected using the same collection method. Soil samples were collected in accordance with current SESP soil sampling procedures (Hanf et al. 2007). The collection of samples consisted of extracting five 10-cm-diameter, 2.5-cm-deep "cookie cutter" samples from each location. These five discrete portions were combined to make one sample for each location. Prior to analysis, the samples collected on the HRNM were split with a riffle splitter, and half of each sample was kept for potential future analysis. Routine samples were separated for the various analyses at the analytical laboratory. Due to the different project objectives, the spatial distribution of sampling locations was not uniform across the sampling areas (Figure 1).

\subsection{Sample Analysis}

Sample analyses were conducted by a subcontracted analytical laboratory in 2008. Sample preparation included sieving (2-mm screen size), drying, and ball milling to achieve a maximum particle size of $300 \mu \mathrm{m}$. For the analysis, EPA method 6020 (inductively coupled plasma-mass spectrometry, ICP-MS) was used, generating results for 29 constituents. Samples collected in 2008 were also analyzed for mercury using cold vapor atomic absorption (CVAA; EPA method 7471). All concentration results were reported on a dry-weight basis. All results are permanently stored, and available upon request, in the Hanford Environmental Information System (HEIS) database. The Appendix to this report provides a discussion of a subset of samples analyzed at a separate analytical laboratory using modified versions of EPA methods 200.7 and 200.8 .

\subsection{Data Analysis}

Results of all sample analyses were evaluated initially on a summary basis. A select group of metals was evaluated further at a more rigorous level of detail. These selected results were compared against regulatory standards, other soil samples collected onsite, Columbia River sediment results, and published concentrations in other similar environments. Selected results also were evaluated visually on a spatial basis to determine if there were any apparent spatial differences.

The Model Toxics Control Act (MTCA) soil cleanup levels for unrestricted land use were used as a regulatory benchmark for comparison (WAC 173-340-740). Four of the metals analyzed for in this 
analysis are included on the MTCA list. Although these concentrations are not directly applicable regulatory concentrations in this instance, they provide a reasonable benchmark for comparison.

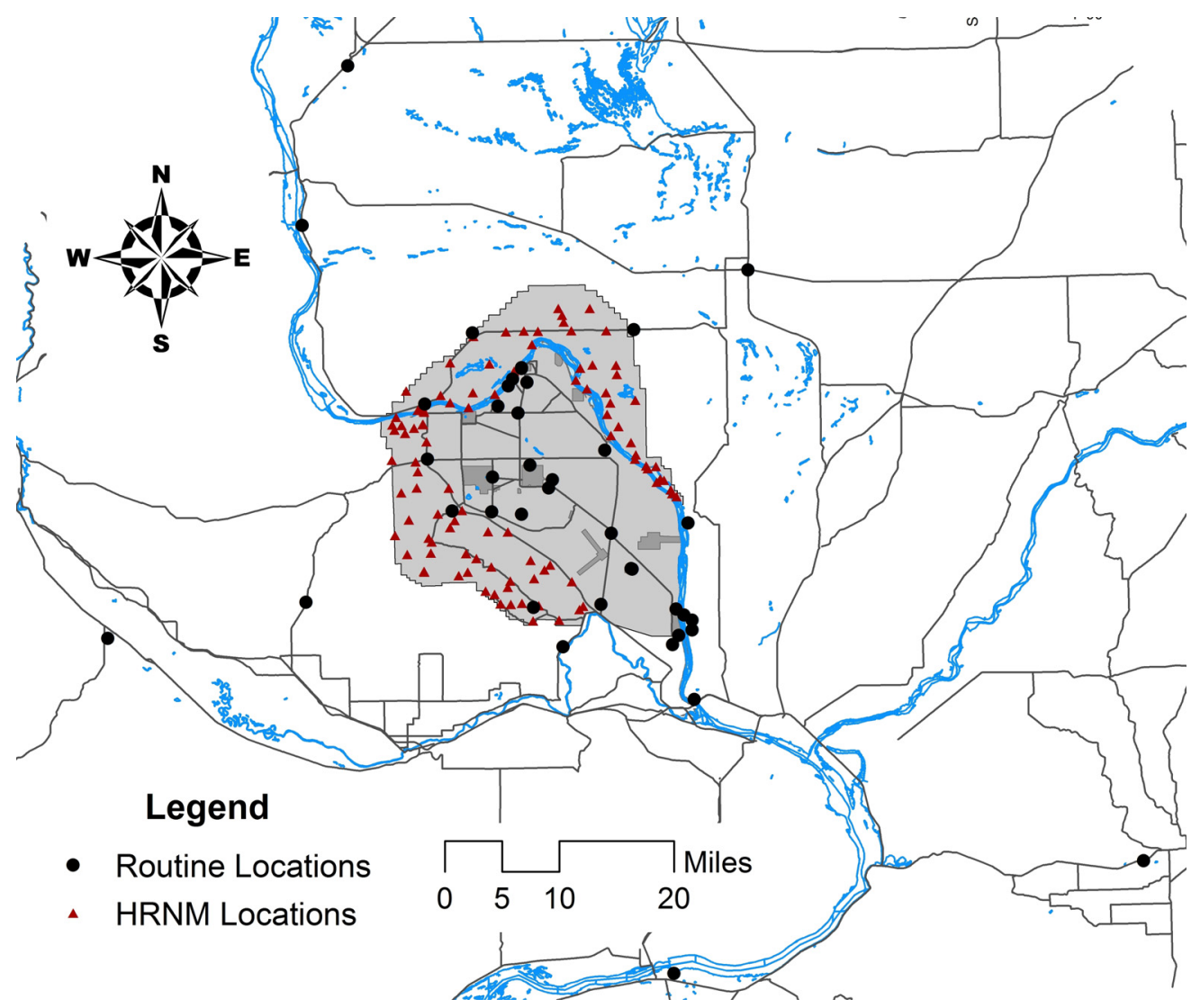

Figure 1. Locations of Soil Samples Collected in 2004, 2005, and 2008 and Analyzed for Metals in 2008. Shaded region is the Hanford Site.

Onsite soil samples have been periodically collected and analyzed for metals as part of various projects and studies on and around the Hanford Site. These samples generally have been drawn from targeted areas with suspected contamination. Results of surface soil samples in the HEIS database are from various locations onsite, including the $100 \mathrm{~B} / \mathrm{C}$ Area (Poston et al. 2005), $100 \mathrm{~N}$ Area (Poston, personal communication, 2008), the 200 Areas Biological Resources Management Plan (BRMaP) plots (Poston et al. 2006), and from reference locations (e.g., Vernita Bridge). Columbia River sediment was collected at known groundwater contaminant discharge points along the Hanford Reach, known sediment accumulation areas along the Hanford Reach, and from behind several dams near the Hanford Site (Poston et al. 2008). For this report, it was assumed that there was only a limited Hanford source of metals relative to the total metal burden in Columbia River sediment, and all Columbia River sediment results were combined for analysis.

The results of surface soil samples were also compared to published soil concentrations at various scales. Comparisons were made against the estimated Hanford background concentrations, southeastern Washington State median concentrations, and mean values in the United States for sandy soils. The Hanford Site background concentrations were determined using a statistical evaluation of 170 samples 
collected across the Hanford Site. For this report, comparisons were made against the mean value of the 170 samples (DOE 1993). At a regional scale, data were compared to results of a Washington State Department of Ecology Study that measured the concentrations of 12 metals in surface soil across the state of Washington (San Juan 1994). Here, we compare results collected on and around the Hanford Site to the median concentrations measured in the southeastern portion of Washington State. For comparison at a national scale, the concentration results were evaluated relative to the mean concentration reported in sandy soil in the United States (Kabata-Pendias 2001).

Spatial analysis of the concentrations was conducted using Surfer, a contouring software package (Golden Software, Inc., Golden, Colorado). The location data and concentrations at each $x, y$ point were loaded into the software package, where a gridded representation of the data was compiled. The gridding was done using a minimum curvature approach. The contoured data were then exported to ArcMap (Environmental Systems Research Institute, Redlands, California) for mapping purposes. 


\subsection{Results and Discussion}

\subsection{Data Summary}

Concentration results for 30 individual metals were generated by the analytical methods for each of the 158 sampling locations. Selenium and antimony were not measured at detectable concentrations in most of the samples (Table 1). Mercury was detected in about half of the samples analyzed. All other constituents were measured at detectable concentrations in nearly all samples analyzed. The concentrations ranged from a few micrograms per kilogram (mercury) to several grams per kilogram (iron). The results for each constituent were not normally distributed, but the skewness coefficient for most compounds was less than 0.1 , so the data were assumed to be normally distributed for the sake of analysis.

Table 1. Results for metals concentrations in soil samples collected on and around the Hanford Site between 2005 and 2008. The 90th percentile is the mean plus 1.28 standard deviations.

\begin{tabular}{|c|c|c|c|c|c|c|}
\hline \multirow[b]{2}{*}{ Element Name } & \multirow{2}{*}{$\begin{array}{l}\text { Element } \\
\text { Symbol }\end{array}$} & \multirow{2}{*}{$\begin{array}{c}\text { Number } \\
\text { Analyzed }\end{array}$} & \multirow{2}{*}{$\begin{array}{l}\text { Number } \\
\text { Detected }\end{array}$} & Mean & Standard Deviation & 90th Percentile \\
\hline & & & & \multicolumn{3}{|c|}{$\mathrm{mg} / \mathrm{kg}$} \\
\hline Aluminum & $\mathrm{Al}$ & 158 & 158 & 12,400 & 4,200 & 17,700 \\
\hline Antimony & $\mathrm{Sb}$ & 158 & 27 & 0.113 & 0.041 & 0.166 \\
\hline Arsenic & As & 158 & 158 & 3.11 & 2.04 & 5.72 \\
\hline Barium & $\mathrm{Ba}$ & 158 & 158 & 106 & 29.1 & 143 \\
\hline Beryllium & $\mathrm{Be}$ & 158 & 158 & 0.365 & 0.126 & 0.526 \\
\hline Boron & B & 158 & 139 & 2.25 & 1.07 & 3.62 \\
\hline Cadmium & $\mathrm{Cd}$ & 158 & 158 & 0.422 & 0.283 & 0.784 \\
\hline Calcium & $\mathrm{Ca}$ & 158 & 158 & 6,190 & 5,000 & 12,600 \\
\hline Chromium & $\mathrm{Cr}$ & 158 & 158 & 12.2 & 4.63 & 18.1 \\
\hline Cobalt & Co & 158 & 158 & 8.02 & 1.96 & 10.5 \\
\hline Copper & $\mathrm{Cu}$ & 158 & 158 & 14.9 & 4.68 & 20.9 \\
\hline Iron & $\mathrm{Fe}$ & 158 & 158 & 23,300 & 5,730 & 30,600 \\
\hline Lead & $\mathrm{Pb}$ & 158 & 158 & 10.3 & 7.67 & 20.1 \\
\hline Lithium & $\mathrm{Li}$ & 158 & 158 & 9.29 & 2.62 & 12.6 \\
\hline Magnesium & $\mathrm{Mg}$ & 158 & 158 & 4,730 & 946 & 5,940 \\
\hline Manganese & $\mathrm{Mn}$ & 158 & 158 & 401 & 110 & 541 \\
\hline Mercury & $\mathrm{Hg}$ & 41 & 20 & 0.0061 & 0.0051 & 0.0127 \\
\hline Molybdenum & Mo & 158 & 158 & 0.364 & 0.280 & 0.722 \\
\hline Nickel & $\mathrm{Ni}$ & 158 & 158 & 11.7 & 3.37 & 16.1 \\
\hline Potassium & $\mathrm{K}$ & 158 & 158 & 2,020 & 622 & 2,810 \\
\hline Selenium & $\mathrm{Se}$ & 158 & 1 & 0.876 & NA & NA \\
\hline Silver & $\mathrm{Ag}$ & 158 & 158 & 0.118 & 0.038 & 0.167 \\
\hline Sodium & $\mathrm{Na}$ & 158 & 158 & 461 & 548 & 1,160 \\
\hline Strontium & $\mathrm{Sr}$ & 158 & 158 & 39.6 & 13.4 & 56.7 \\
\hline Thallium & $\mathrm{Tl}$ & 158 & 157 & 0.129 & 0.062 & 0.209 \\
\hline Titanium & $\mathrm{Ti}$ & 158 & 158 & 1,240 & 364 & 1,700 \\
\hline Uranium & $\mathrm{U}$ & 53 & 53 & 0.731 & 0.467 & 1.33 \\
\hline Vanadium & V & 158 & 158 & 49.3 & 16.0 & 69.7 \\
\hline Zinc & $\mathrm{Zn}$ & 158 & 158 & 62.8 & 43.9 & 119 \\
\hline Zirconium & $\mathrm{Zr}$ & 158 & 158 & 23.2 & 9.39 & 35.2 \\
\hline
\end{tabular}


For metals listed in the MTCA, the average concentrations measured in this study were well below the soil cleanup levels for unrestricted land use (Table 2). In addition to the average concentration being less than the MTCA benchmark, the 90th percentile concentration also was lower than the benchmark for these four metals.

Table 2. Comparison of Model Toxics Control Act Metals Cleanup Levels for Unrestricted Use and Measured Concentrations of Listed Metals

\begin{tabular}{|c|c|c|c|}
\hline Element Name & $\begin{array}{l}\text { MTCA Cleanup } \\
\text { Level }^{(a)}(\mathrm{mg} / \mathrm{kg})\end{array}$ & Mean $(\mathrm{mg} / \mathrm{kg})$ & $\begin{array}{c}\text { 90th Percentile } \\
(\mathrm{mg} / \mathrm{kg})\end{array}$ \\
\hline Arsenic & 20 & 3.11 & 5.72 \\
\hline Cadmium & 2 & 0.422 & 0.784 \\
\hline Lead & 250 & 10.3 & 20.1 \\
\hline Mercury & 2 & 0.0061 & 0.0127 \\
\hline
\end{tabular}

(a) Method A, unrestricted land use cleanup levels (WAC 173-340-740, Table 740-1).

(b) Mean value plus 1.28 standard deviations.

\subsection{Comparison of Results to Other Data}

Concentrations of metals measured in surface soils for this study were also compared to measurements of metals concentrations in soil collected for risk assessment studies and sediment collected from the Columbia River. The concentration of metals measured in surface soil is generally lower than concentrations measured in Columbia River sediments and in risk assessment studies, but within the range of normal variation (Figure 2). This difference is likely attributable to the fact that samples collected by previous Hanford Site studies used a different laboratory for analysis (Appendix). However, surface soil samples may be somewhat lower because samples for risk assessment and sediment samples are collected at locations that specifically target suspected contamination. The slightly lower surface soil concentrations could also be an artifact of the sampling location; risk assessment and sediment samples probably were collected from areas with higher organic content. Samples with higher organic carbon content typically have higher, naturally occurring concentrations of metals (DOE 1993). 


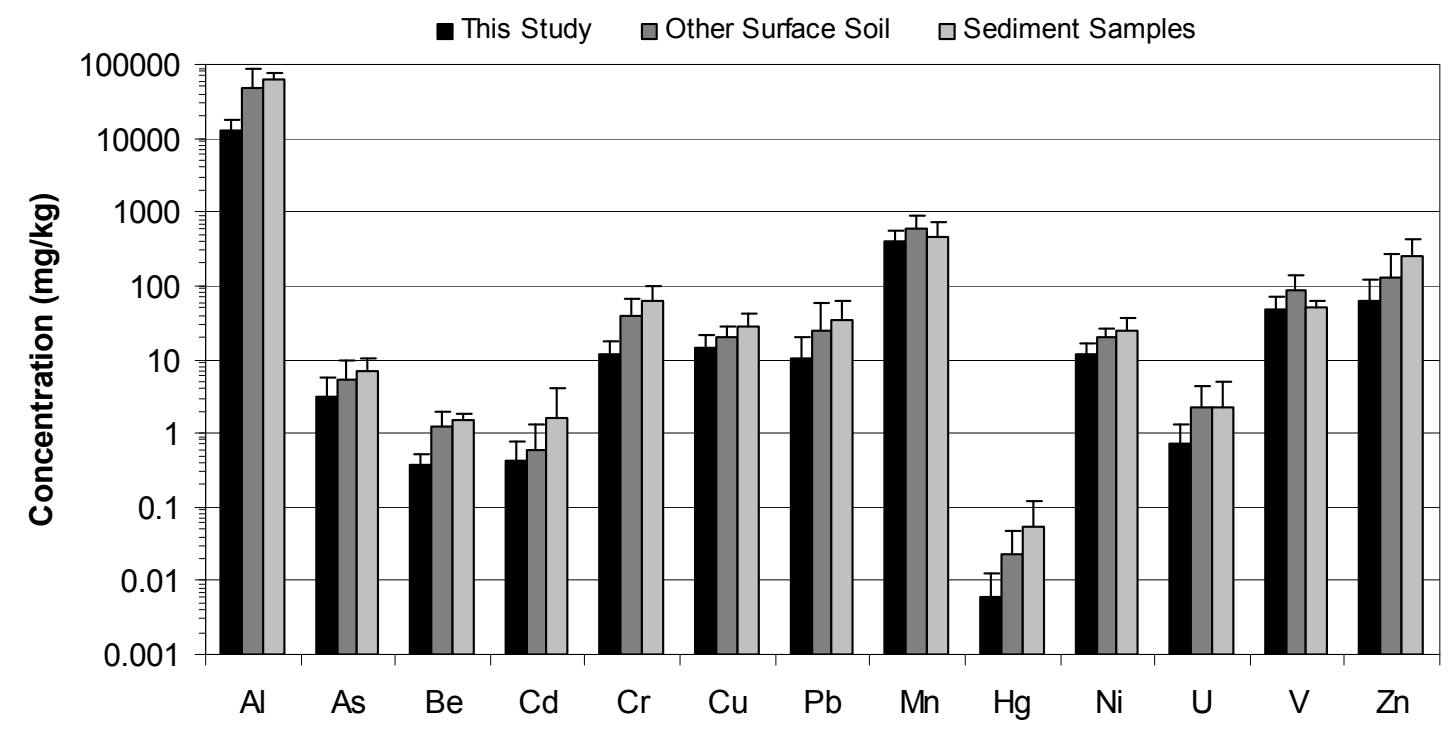

Figure 2. Average of Samples Collected on the Hanford Site for This Study and for Risk Studies, and of Samples of Columbia River Sediment Analyzed for Metals. Whiskers represent the 90th percentile values.

Comparison of the results of this study against the estimated Hanford Site background (DOE 1993), the average southeastern Washington State concentrations (San Juan 1994), and the average U.S. concentration for sandy soil (Kabata-Pendias 2001) indicated that the concentrations of metals measured on and around the Hanford Site were within the range of concentrations measured in other similar areas (Figure 3). For the comparison to average U.S. soil concentration (for sandy soil), only the average is provided.

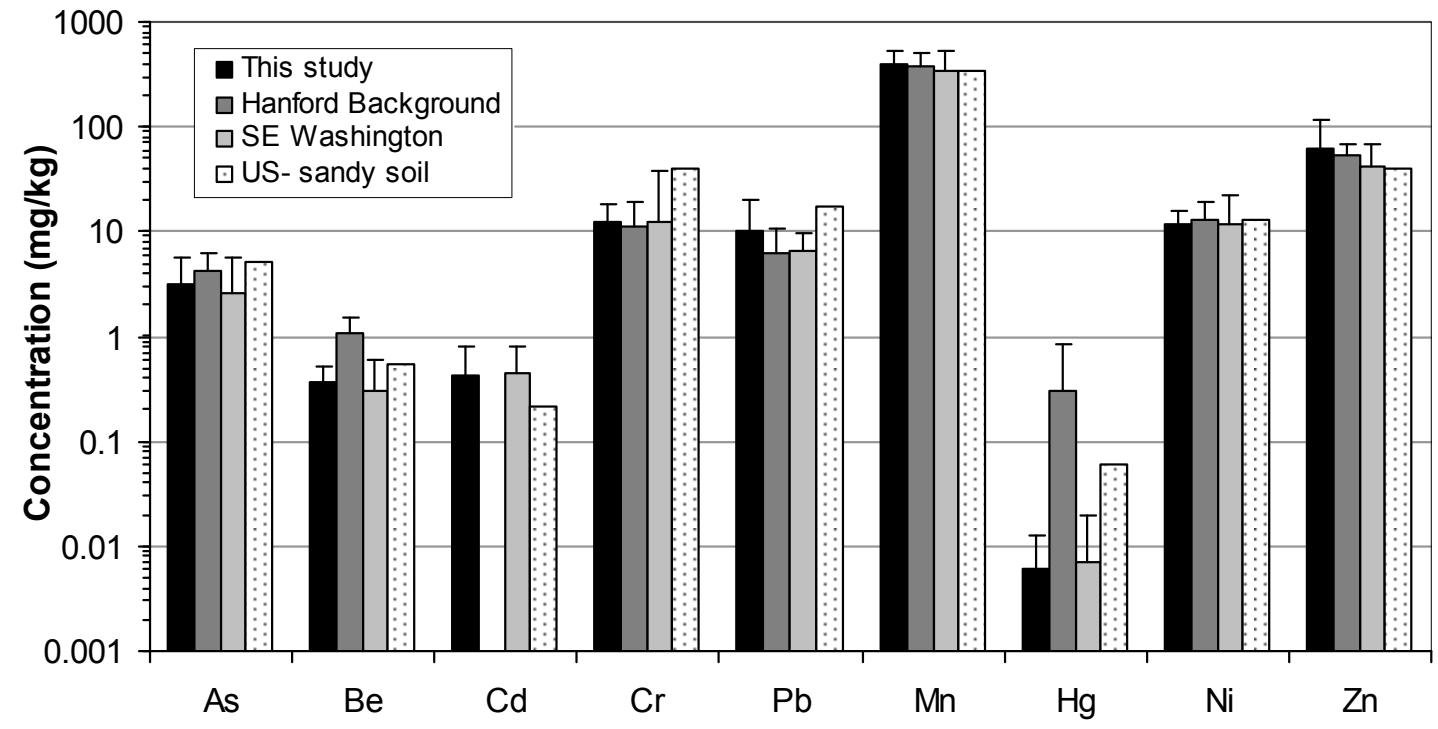

Figure 3. Selected Metals Concentrations Measured on and Around the Hanford Site Compared to Hanford Background Concentrations, Southeastern Washington Averages, and U.S. Average for Sandy Soils. Whiskers represent the 90th percentile values. 


\subsection{Spatial Analysis}

A visual evaluation of the contoured data for all metals indicated that there were no large local sources of metal contamination. Any large local sources would have shown a localized concentration gradient around the source; this was not the case. Although some bulls-eyes were generated in some of the contoured data, they were artifacts of the contouring software and the non-uniform spatial distribution of data. For example, the modeled concentrations of arsenic were uniform across most of the Hanford Site, with the exception of the dune region located east of the 200 Areas (Figure 4). However, no actual samples had been collected from this region, so the seemingly high concentrations were simply an artifact of the contouring software. This highlights an important disclaimer about contouring software; the modeled contours are valid only when the spatial density of the data is such that there are actual data points within the contour lines.

It is worth noting that this artificially high contour was fit by the software to account for one sample collected from the eastern shoreline of the Columbia River that had an elevated arsenic concentration. The sample from this location had the highest measured concentrations of arsenic, chromium, copper, iron, nickel, and antimony measured in this study and was among the highest concentrations for several other metals. A visit to this sampling site confirmed that this location had a high silt and clay fraction, likely accounting for the higher concentrations of metals in that sample. However, this area had been used as an orchard before the Hanford Site was established, so there is a possibility that some of the metals present in this sample originated from farming activities.

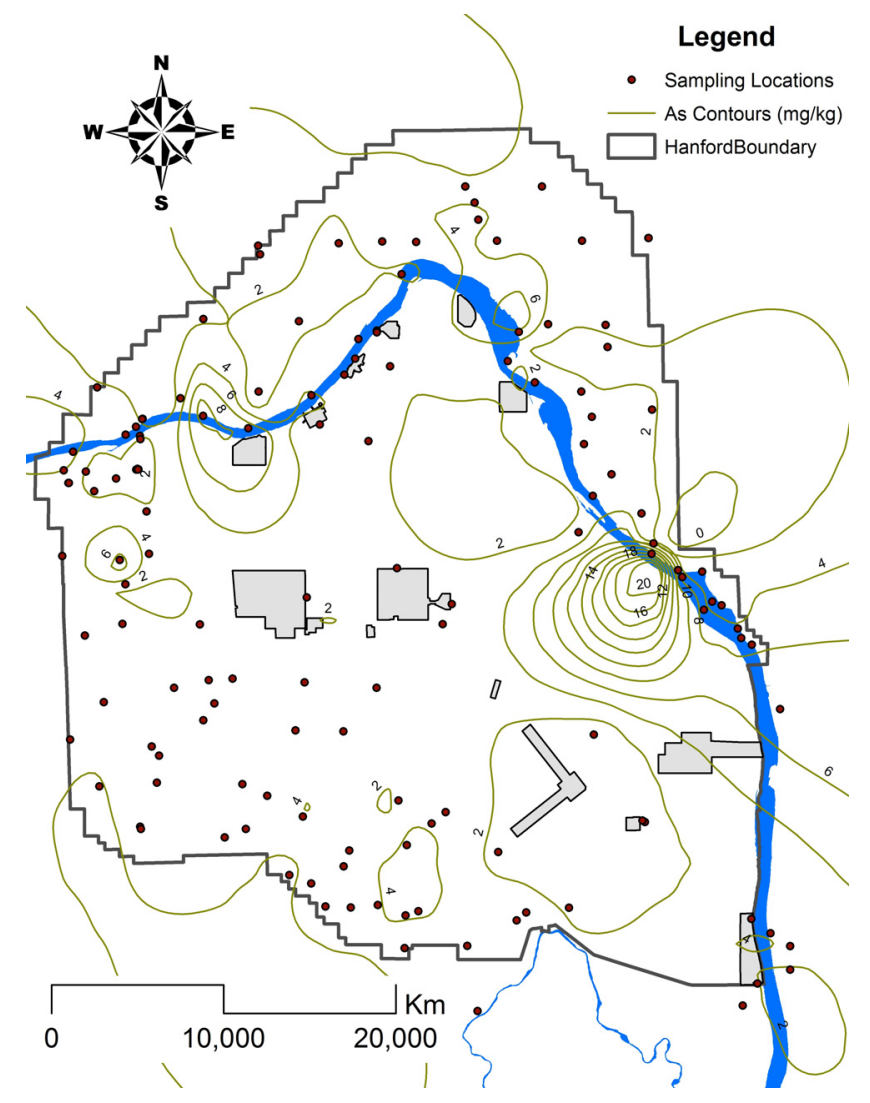

Figure 4. Contoured Arsenic Concentrations in Surface Soil Relative to Sample Locations 


\subsection{Conclusions}

The analysis of total metal concentrations in surface soil collected on and around the Hanford Site between 2004 and 2008 yielded results indicating that the measured concentrations of metals in surface soil were within the expected range of concentrations. The measured values are consistent also with previous results from samples collected on and around the Hanford Site. 


\subsection{References}

Bisping LE. 2008. Hanford Site Environmental Surveillance Schedule Master Sampling Schedule for Calendar Year 2008. PNNL-17282, Pacific Northwest National Laboratory, Richland, Washington.

EPA Method 200.7. 1994. "Determination of Metals and Trace Elements in Water and Wastes by Inductively Coupled Plasma-Atomic Emission Spectrometry." Revision 4.4, Environmental Monitoring Systems Laboratory, Office of Research and Development, U.S. Environmental Protection Agency, Cincinnati, Ohio.

EPA Method 200.8. 1994. "Determination of Trace Elements in Waters and Wastes by Inductively Coupled Plasma - Mass Spectrometry." Revision 5.4, Environmental Monitoring Systems Laboratory, Office of Research and Development, U.S. Environmental Protection Agency, Cincinnati, Ohio.

EPA Method 6020. 2007. "Inductively Coupled Plasma-Mass Spectrometry." SW-846 Revision 6, U.S. Environmental Protection Agency, Washington DC.

EPA Method 7471. 2007. "Cold Vapor Atomic Absorbance.” SW-846 Revision 6, U.S. Environmental Protection Agency, Washington DC.

Fritz BG, RL Dirkes, and BA Napier. 2007a. Soil Sampling to Demonstrate Compliance with Department of Energy Radiological Clearance Requirements for the ALE Unit of the Hanford Reach National Monument. PNNL-14937 Rev. 1, Pacific Northwest National Laboratory, Richland, Washington.

Fritz BG, RL Dirkes, and BA Napier. 2007b. Soil Sampling to Demonstrate Compliance with Department of Energy Radiological Clearance Requirements for the McGee Ranch-Riverlands and North Slope Units of the Hanford Reach National Monument. PNNL-16883, Pacific Northwest National Laboratory, Richland, Washington.

Fritz BG and RL Dirkes. 2005. Soil Sampling and Analysis Plan for the McGee Ranch-Riverlands and North Slope Units of the Hanford Reach National Monument. PNNL-14950, Pacific Northwest National Laboratory, Richland, Washington.

Fritz BG, TM Poston, and RL Dirkes. 2004. Fitzner-Eberhardt Arid Lands Ecology (ALE) Reserve Soil Sampling and Analysis Plan. PNNL-14663, Pacific Northwest National Laboratory, Richland, Washington.

Hanf RW, TM Poston, and LE Bisping. 2007. Surface Environmental Surveillance Procedures Manual, PNL-MA-580, Rev. 5. PNNL-16744, Pacific Northwest National Laboratory, Richland, Washington.

Kabata-Pendias A. 2001. Trace Elements in Soils and Plants. CRC Press, Boca Raton, Florida.

Poston TM, BL Tiller, JL Downs, GW Patton, KA Gano, and JK Linville. 2005. 100-B/C Pilot Project Data Summary for 2003 and 2004. BHI-07124, Bechtel Hanford, Inc., Richland, Washington.

Poston TM, RW Hanf, RL Dirkes, and LF Morasch. 2006. Hanford Site Environmental Report for Calendar Year 2005. PNNL-15892, Pacific Northwest National Laboratory, Richland, Washington. 
Poston TM, JP Duncan, and RL Dirkes. 2008. Hanford Site Environmental Report for Calendar Year 2007. PNNL-17603, Pacific Northwest National Laboratory, Richland, Washington.

Poston TM, JP Duncan, and RL Dirkes. 2009. Hanford Site Environmental Report for Calendar Year 2008. PNNL-18427, Pacific Northwest National Laboratory, Richland, Washington.

San Juan C. 1994. Natural Background Soil Metals Concentrations in Washington State. Publication 94-115, Washington State Department of Ecology, Olympia, Washington.

U.S. Department of Energy (DOE). 2001. A Report to Congress Detailing DOE's Existing and Anticipated Long-Term Stewardship Obligations. DOE/EM-0563, U.S. Department of Energy, Office of Environmental Management, Washington, D.C.

U.S. Department of Energy (DOE). 1993. Hanford Site Background Part 1, Soil Background for Nonradioactive Analytes. DOE/RL-92-24, Rev. 1, U.S. Department of Energy, Richland Operations Office, Richland, Washington. 



\section{Appendix}

\section{Inter-Laboratory Comparison}





\section{Appendix}

\section{Inter-Laboratory Comparison}

Nine of the samples collected by the SESP in 2008 for metals analysis were split using a riffle splitter, which was cleaned after each use. Half of the sample was analyzed by the subcontracted analytical laboratory as described in Section 2.3. The other half of the sample was analyzed by the Pacific Northwest National Laboratory Marine Sciences Laboratory (MSL) located in Sequim, Washington. This laboratory routinely analyzes environmental media for trace levels of contaminants (including metals) and is the laboratory previously used for analysis of metals in Hanford Site soil and sediment. The MSL uses modified versions of EPA methods 200.7 and 200.8 for ICP-MS analysis, and a modified version of 245.5 CVAA for mercury.

The results of these nine split samples were compared as a quality control check of the subcontracted laboratory. The results were typically in good agreement, although the samples analyzed by the subcontracted laboratory were typically reported with a lower concentration than the results reported by the MSL (Figure A.1). This was likely a systematic difference that resulted from differences in sample preparation and analytical procedures used by the different laboratories. Because the MSL analyzed previous Hanford Site sediment and soil samples, the average result of all 158 samples analyzed for each constituent in this study (fewer for uranium and mercury) was adjusted to an equivalent MSL value. This was accomplished by multiplying the ratio of the average concentration for each analyte from each laboratory by the result from the subcontracted laboratory (Table A.1). This adjustment step resulted in even better agreement between the concentrations in samples collected for this study and results in sediment and previously collected surface soil (Figure A.2). The difference between the results obtained by the two laboratories is most likely an artifact of the methods used and not an indication of poor performance by one laboratory or another. 


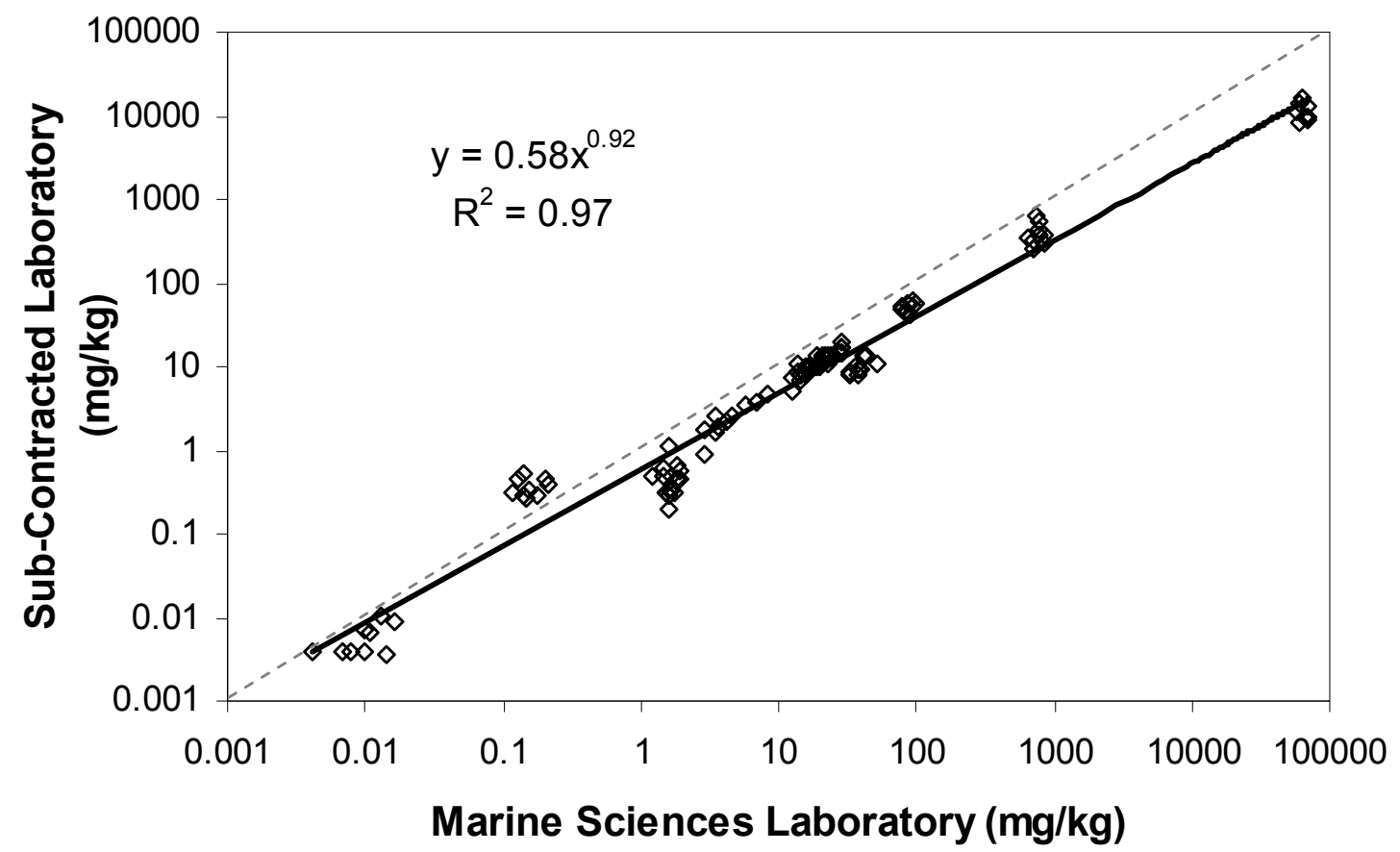

Figure A.1. Regression Plot Comparing Results from the Two Analytical Laboratories for All Constituents Analyzed for in the Nine Split Samples

Table A.1. Average concentrations and Calculated Adjustment Factor for the Nine Split Samples

\begin{tabular}{lccc}
\hline \multicolumn{1}{c}{ Element Name } & $\begin{array}{c}\text { MSL Mean } \\
(\mathrm{mg} / \mathrm{kg})\end{array}$ & $\begin{array}{c}\text { Subcontracted Lab } \\
\text { Mean }(\mathrm{mg} / \mathrm{kg})\end{array}$ & $\begin{array}{c}\text { Adjustment } \\
\text { Factor }\end{array}$ \\
\hline Aluminum & 65060 & 11058 & 5.9 \\
Arsenic & 4.8 & 2.7 & 1.8 \\
Beryllium & 1.7 & 0.3 & 5.0 \\
Cadmium & 0.16 & 0.37 & 0.4 \\
Chromium & 39 & 10 & 3.9 \\
Copper & 26 & 14 & 1.8 \\
Mercury & 0.0104 & 0.0058 & 1.8 \\
Manganese & 760 & 401 & 1.9 \\
Nickel & 16.8 & 10.3 & 1.6 \\
Lead & 17.2 & 10.0 & 1.7 \\
Uranium & 1.8 & 0.6 & 2.8 \\
Zinc & 88 & 51 & 1.7 \\
\hline
\end{tabular}




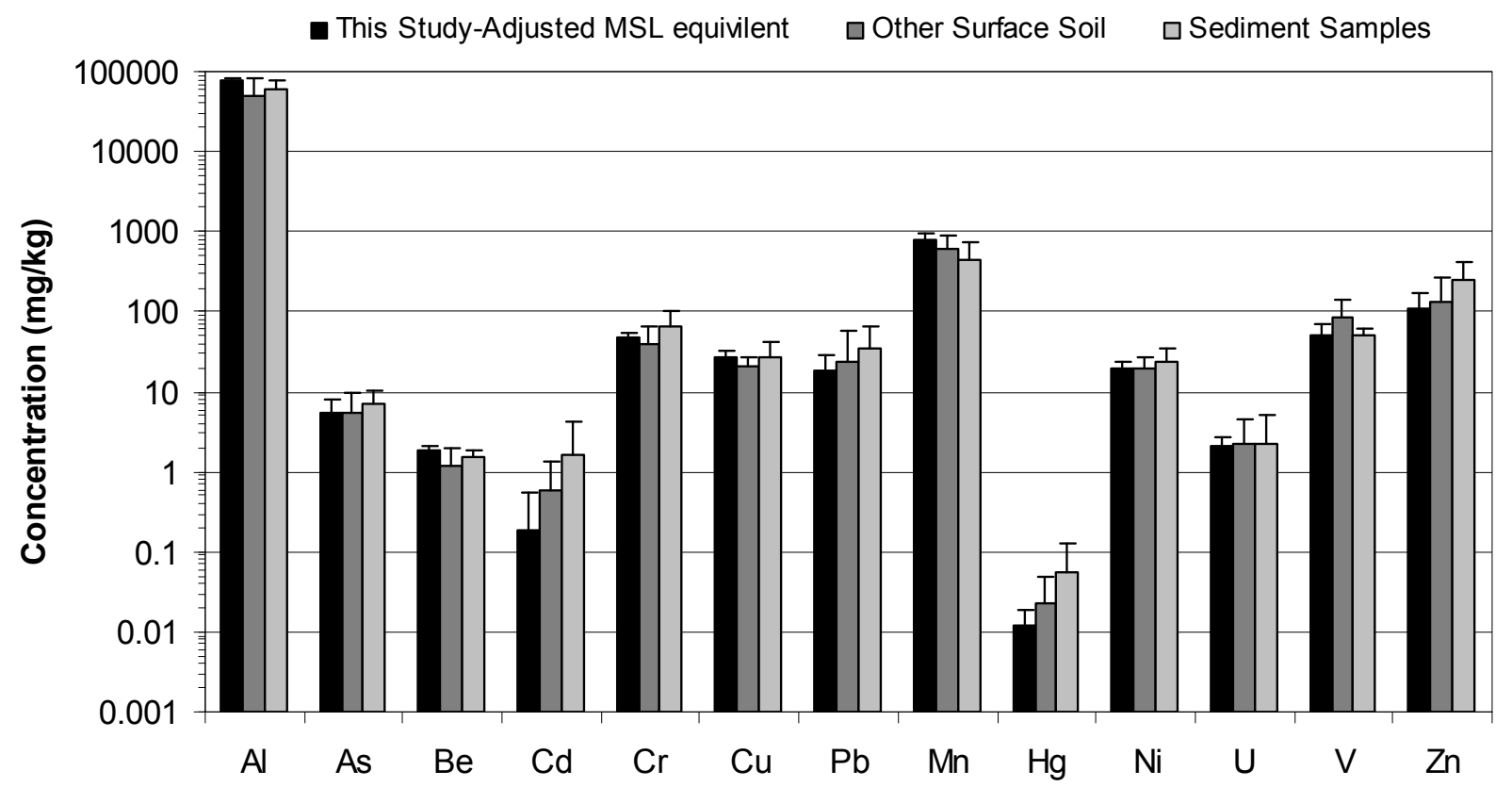

Figure A.2. Comparison of Previous Onsite Sample Results with the Results of This Study Adjusted to MSL Equivalent Values. This is a repeat of Figure 2, with adjusted concentrations using the adjustment factor shown in Table A.1. 



\section{Distribution}

No. of

Copies

\section{OFFSITE}

C. Andrade

NOAA

7600 Sand Point Way NE

Seattle, WA 98115

G. Bohnee, Director

Nez Perce Tribe

P.O. Box 365

Lapwai, ID 83540

R. (Bobby) Brunoe, GW Natural Resources

Confederated Tribes of the Warm Springs

Reservation

P.O. Box 1299

Warm Springs, OR 97761

L. Buck

Wanapum

P.O. Box 878

Ephrata, WA 98823

R. Buck, Jr.

Wanapum

P.O. Box 878

Ephrata, WA 98823

M. Hunter

600 Capitol Way, North Loc.

1111 Washington St. SE

Olympia, WA 98501-1091
No. of

Copies

L. Gadbois

U.S. Environmental Protection Agency

309 Bradley Boulevard, Suite 115

Richland, WA 99352

L. Goldstein

Hanford Natural Resources Trustee Council Washington State Department of Ecology

P.O. Box 47600

Olympia, WA 98504

T. Davidson

U.S. Fish and Wildlife Service

11103 East Montgomery Drive

Spokane, WA 99206

B. Harper

Confederated Tribes of the Umatilla Indian Reservation

750 Swift, Suite 14

Richland, WA 99352

R. Cruz

Confederated Tribes of the Umatilla Indian

Reservation

750 Swift, Suite 14

Richland, WA 99352

S. Harris

Confederated Tribes of the Umatilla Indian

Reservation

P.O. Box 638

Pendleton, OR 97801 
No. of

Copies

G. Hughes

U.S. Fish and Wildlife Service

64 Maple Street

Burbank, WA 99323

R. Jim, Manager

Environmental Restoration and Waste

Management Program

The Confederated Tribes and Bands of the

Yakama Nation

2808 Main Street

Union Gap, WA 98903

D. Landeen

Nez Perce Tribe

109 Lolo Street

Lapwai, ID 83540

D. McBaugh

Division of Radiation Protection

Washington State Department of Health

P.O. Box 47890

Olympia, WA 98504-7890

J. McConnaughey

Yakama Nation

P.O. Box 6066

Kennewick, WA 99336-0066

A. Nomee, Dept. of Natural Resources

Coeur d'Alene Tribe

P.O. Box 408

Plummer, ID 83851-9704
No. of

\section{Copies}

C. Pleasants

Confederated Tribes of the Colville

Reservation

P.O. Box 150

Nespelem, WA 99155

J. Price

Washington Department of Ecology

3100 Port of Benton Boulevard

Richland, WA 99354

M. Priddy

Washington State Department of Health 309 Bradley Boulevard

Richland, WA 99352

M. Ritter

U.S. Fish and Wildlife Service

64 Maple Street

Burbank, WA 99323

P. Shaffer

Oregon Department of Energy

625 Marion Street NE

Salem, OR 97301-3737 
No. of

Copies

\section{ONSITE}

\section{DOE Richland Operations Office}

B. L. Foley

A6-38

H. B. Hathaway

A. R. Hawkins

J. P. Sands

D. C. Ward (5)

J. H. Zeisloft

DOE Public Reading Room (2)

Hanford Site Administrative

Record (2)

A3-04

A7 -50

A3-04

A2-17

A3-04

H2-53

H6-08
No. of

$\underline{\text { Copies }}$

2 Fluor Hanford, Inc.

R. G. Bauer

E6-44

A. R. Johnson

$\mathrm{H} 8-26$

D. Jacques
2 Washington Closure Hanford

$\mathrm{H} 4-22$

L. C. Hulstrom

H4-22

13 Pacific Northwest National Laboratory

E. J. Antonio

K3-54

R. L. Dirkes

K6-75

B. G. Fritz (5)

K6-75

G. W. Patton

K6-75

T. M. Poston

K6-75

A. Stegen

K3-66

Hanford Technical Library (2)

P8-55

LMSI Central Files

B1-07 




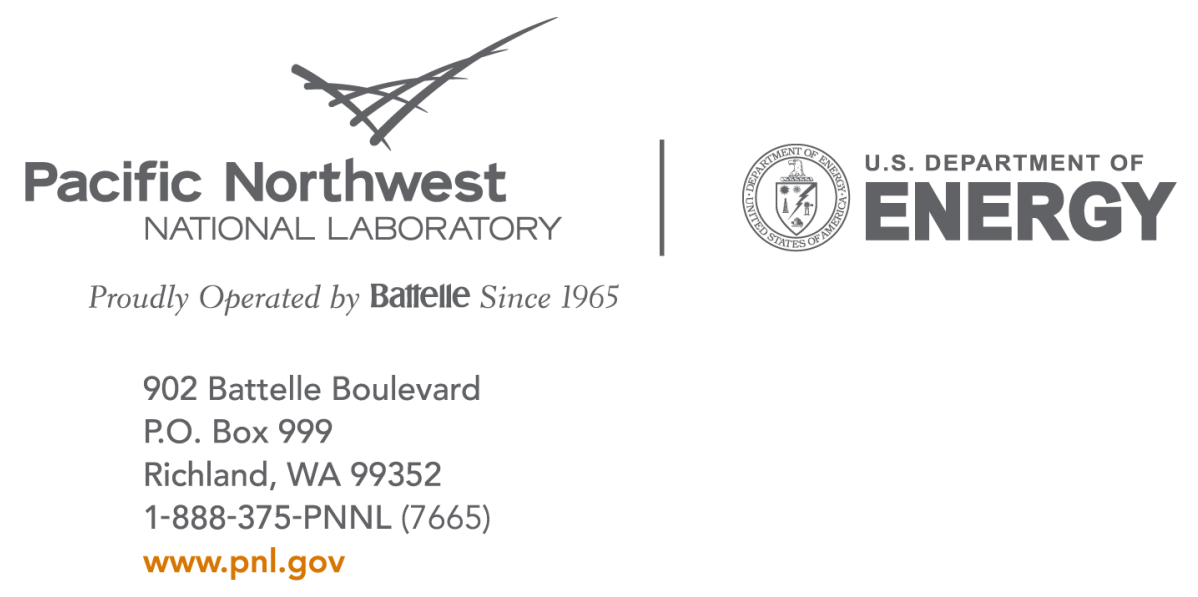

